\title{
Ultrasound lumbar canal measurement in hospital employees with back pain
}

\author{
D J ANDERSON, D F ADCOCK, A C CHOVIL, J J FARRELL
}

From the Departments of Preventive Medicine and Radiology, University of South Carolina School of Medicine, and Department of Radiology, Wm Jennings Bryan Dorn Veterans' Hospital, Columbia, South Carolina 29208, USA

ABSTRACT The oblique parasagittal diameter of the lumbar spinal canal at the L5-S1 level was measured in 49 employees of the Wm Jennings Bryan Dorn Veterans' Hospital using real time ultrasound in a case-control study. Individuals with a canal diameter of less than $14 \mathrm{~mm}$ represented the lowest 10th percentile in this population and being in the narrowest 10th percentile constituted a risk factor for time missed from work because of low back pain (odds ratio 10.7). Whereas numbers in this pilot study are small, results are consistent with earlier ultrasound studies done in the United Kingdom and with other research showing increased morbidity from low back pain in individuals with small lumbar canals. Ultrasound has advantages over other modalities for measuring the size of the lumbar canal and may be useful as a preplacement screening examination in industry.

Low back pain (LBP) is a common condition that costs industry billions of dollars annually in workers' compensation claims alone. ${ }^{12} \mathrm{~A}$ few claims result in a disproportionate amount of cost. ${ }^{23}$ In a study of Boeing Company employees $10 \%$ of claims accounted for $79 \%$ of the total costs from LBP. ${ }^{4}$ If workers at increased risk for developing high cost back injuries could be identified before injury occurs special training or job placement, or both, might lower their risk of serious low back disability, which would reduce both employee suffering and employer costs.

An anatomically narrow lumbar spinal canal is associated with increased morbidity arising from at least three major conditions: intervertebral disc disease, neurogenic claudication (spinal stenosis syndrome), and root entrapment syndromes. The clinical importance of a stenotic lumbar canal has been increasingly understood in recent decades. ${ }^{s-21}$ The usefulness of this knowledge, however, has been severely limited by the difficulty in obtaining in vivo canal measurements without undue cost, exposure to radiation, or discomfort. ${ }^{22}$

In 1978 Porter et al first showed that midsagittal lumbar spinal canal diameters could be measured by ultrasound. ${ }^{23}$ They determined that lumbar canals were smaller in patients with disc symptoms than in controls, and that the greater the morbidity the smaller the canal size. ${ }^{1213}$ Macdonald $e t$ al, using ultrasound,

Accepted 24 August 1987 looked at 204 British coalminers and also found a strong tie between narrow lumbar canals and increased morbidity from LBP. ${ }^{16}$ Since ultrasound examinations do not expose individuals to ionising radiation, and since the procedure is non-invasive, painless, and may be performed quickly and relatively inexpensively, it has decided advantages over other methods that may be used to measure canal diameters.

This case-control study was undertaken as a pilot project. Its purpose was twofold: to confirm the observations of Porter et al that ultrasound may, in fact, be used to measure lumbar spinal canal diameters accurately ${ }^{1213}$ and to determine if an association between narrow lumbar canal diameters and time lost from work because of low back pain could be found in hospital workers (hospital workers do have a higher than usual incidence of low back injuries). ${ }^{1}$ It is hoped that a long term prospective cohort study of employees at a veterans' hospital will follow.

\section{Materials and methods}

\section{SUBJECTS}

Volunteers for the study were recruited from current employees of a VA hospital. Sixteen employees who had missed time from work in the past two years because of low back pain constituted the "back" group. The "control" group consisted of 23 employees who denied ever having had low back pain of consequence. Those with previous low back surgery (which distorts ultrasound images) were excluded. All 
participants were interviewed at the time informed consent was obtained for the procedure. Those in the back group were asked if they had had radiation of their LBP into their buttock(s) or leg(s). No physical examination or record review was done.

The mean age for the back group was 42.9 years and $40 \cdot 1$ for the controls $(p=0 \cdot 19)$. Mean height did not differ significantly between the groups $(173 \mathrm{~cm}$ for the back group; $171 \mathrm{~cm}$ for controls), although the back group tended to weigh more than the controls$76.5 \mathrm{~kg} v 70.0 \mathrm{~kg}(\mathrm{p}=0.08)$. Mean Quetelet scores were 25.52 for the backs and 23.75 for the controls $(p<0.06)$. The back group differed significantly from the controls in having a greater proportion of jobs where lifting was routinely carried out $(p=0.005)$.

\section{PROCEDURE}

Two dimensional B-mode oblique parasagittal ultrasound images of the lumbar spine at the L5-S1 level were obtained using a Picker real time ultrasound machine with a $10.5 \mathrm{~cm}$ linear array transducer having a frequency of 3.5 megahertz. This standard equipment is used for a wide range of imaging procedures in a medium sized VA hospital. The L5-S1 level was readily identifiable in relation to the visualised sacrum using the linear array transducer. The transducer was placed $1 \mathrm{~cm}$ from the midline of the back and was angled medially approximately $15^{\circ}$ to obtain the best image. Images were displayed both in A and B modes. The A-mode display is relative to the position of the curser on the B-mode display, which should be positioned to conform with the B-mode image. Adjustments to the time delay gain were important to provide optimal display of the anterior and posterior canal margins. This had to be done subjectively on an individual basis. Images were recorded in a 6 on 1 format on to an $8 \times 10$ sheet of film using the Picker multiformat camera.

Imaging was more readily done with subjects in the sitting position (with backs flexed slightly to straighten the lumbar lordotic curve). Satisfactory studies could be completed in about five minutes compared with somewhat inferior studies in 35-45 minutes obtained from subjects in the prone position (where the lumbar lordosis could not be straightened even with pillows under the abdomen). The subjects much preferred the sitting position. This sitting technique for this purpose has not, to the authors' knowledge, been previously reported.

\section{ANALYSIS}

Sixty three sitting studies were completed ( 20 backs and 43 controls). Eleven films of poor quality were excluded from analysis as were three that had incorrect or illegible identification labels. This left $\mathbf{4 9}$ studies for analysis ( 16 backs, 33 controls).
Table 1 Interobserver comparisons

\begin{tabular}{llllll}
\hline Reader & No & $\begin{array}{l}\text { Mean canal } \\
\text { diameter } \\
(\mathrm{cm})\end{array}$ & $\begin{array}{l}\text { Standard } \\
\text { deviation }\end{array}$ & $\begin{array}{l}\text { Correlation } \\
\text { coefficient } \\
\text { (Corr DFA) }\end{array}$ & $R^{2}$ \\
\hline DFA & 49 & 1.68 & 0.24 & - & - \\
DJA & 49 & 1.68 & 0.24 & 0.90 & 0.81 \\
JJF & 27 & 1.73 & 0.25 & 0.81 & 0.66 \\
\hline
\end{tabular}

All films were read by two of the authors, one the chief of the department of radiology at the University of South Carolina School of Medicine (DFA) and the other a boarded internist without special training in radiology (DJA). A second radiologist, the chief of radiology at the Wm Jennings Bryan Dorn Veterans' Hospital (JJF), read 27 films. Measurements were estimated to the nearest $0.05 \mathrm{~cm}$ using an accompanying scale with each set of films. Analysis of interobserver error was made from the results of all three readers. Subsequent group and sub group analyses were performed using the measurements of just one of the authors (DFA). He was totally blinded as to the identity of the films (DJA was not) and he read all the films (JJF did not).

\section{Results}

INTEROBSER VER VARIATION (table 1)

The mean diameter for the group $(\mathrm{cm})$ was $1.68,1.68$, and 1.73 for each reader (DFA, DJA, and JJF). Correlation analysis was performed and the correlation coefficient as compared with DFA values was 0.90 $\left(r^{2}=0.81\right)$ for DJA, and $0.81\left(r^{2}=0.66\right)$ for JJF. The correlation coefficient for DJA compared with JJF was $0.87\left(r^{2}=0.76\right)$. This was thought to represent a high degree of correlation between readers.

GROUP RESULTS (table 2)

The mean L5-S1 canal diameter for the group $(\mathrm{n}=$ 49) was $1.68 \mathrm{~cm}$ (SD 0.24), with a range of $1 \cdot 15$ $2.20 \mathrm{~cm}$ (figure). For the backs, the mean diameter was smaller than the controls- $1.60 \mathrm{~cm}$ (SD 0.25) $v$ $1.72 \mathrm{~cm}(S D 0.23)(p=0.05)$. The four smallest canal diameters were all from the back group $(p<0.01)$. The lowest 10th percentile for the group was found to include diameters of $1.35 \mathrm{~cm}$ or less. The odds ratio for being in the lowest 10th percentile and having missed

Table 2 Group results

\begin{tabular}{|c|c|c|c|c|}
\hline & No & $\begin{array}{l}\text { LS-SI } \\
\text { canal } \\
\text { diameter } \\
(\mathrm{cm})\end{array}$ & $\begin{array}{l}\text { Standard } \\
\text { deviation }\end{array}$ & p Value \\
\hline $\begin{array}{l}\text { Total group } \\
\text { Back group } \\
\text { Control group }\end{array}$ & $\begin{array}{l}49 \\
16 \\
33\end{array}$ & $\begin{array}{l}1.68 \\
1.60 \\
1.72\end{array}$ & $\left.\begin{array}{l}0.24 \\
0.25 \\
0.23\end{array}\right\}$ & 0.05 \\
\hline
\end{tabular}


All subjects $(n=49)$

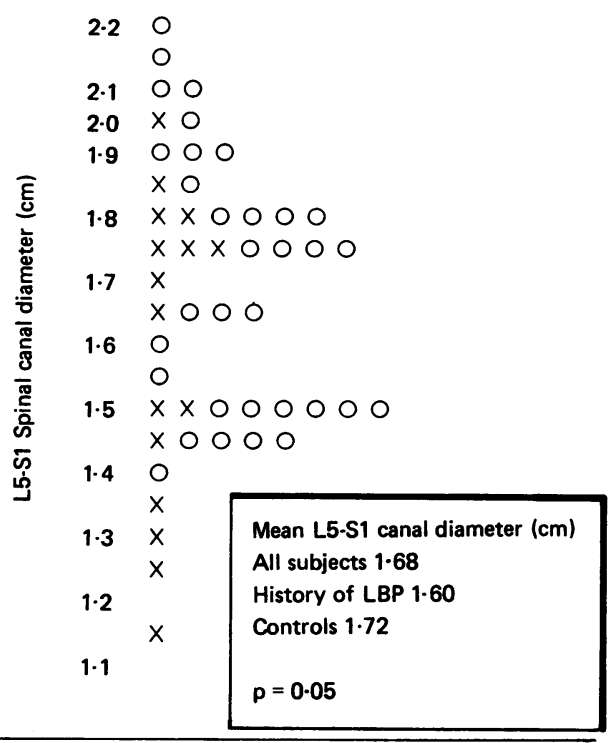

$X=$ History of missed time from work due to low back pain $(n=16)$

$O=$ No history of low back pain $(n=33)$

Distribution of canal diameters.

time from work because of low back pain was calculated to be $10 \cdot 7$.

Canal diameters within the back subgroup $(n=16)$ were examined in relation to the questionnaire response indicating either radiation of the pain into the buttock or leg $(n=7)$ or non-radiation of pain $(n=9)$. No difference was observed between the groups $(1.60 v$ $1.59 \mathrm{~cm})$.

BY SEX (table 3)

The mean canal diameter for 26 men was $1.68 \mathrm{~cm}$ (SD $0 \cdot 28$ ). This did not differ significantly from that of 23 women $-1.67 \mathrm{~cm}$ (SD 0.19). Nor was any significant difference observed between seven women in the back group and 16 women in the control group $-1.67 \mathrm{~cm} \mathrm{v}$

Table 3 Results by sex

\begin{tabular}{|c|c|c|c|c|}
\hline & No & $\begin{array}{l}\text { L5-SI } \\
\text { canal } \\
\text { diameter } \\
(\mathrm{cm})\end{array}$ & $\begin{array}{l}\text { Standard } \\
\text { deviation }\end{array}$ & p Value \\
\hline $\begin{array}{l}\text { Men } \\
\text { Women } \\
\text { Men. }\end{array}$ & $\begin{array}{l}26 \\
23\end{array}$ & $\begin{array}{l}1.68 \\
1.67\end{array}$ & $\begin{array}{l}0 \cdot 28 \\
0 \cdot 19\end{array}$ & 0.53 \\
\hline $\begin{array}{l}\text { Men: } \\
\text { Back } \\
\text { Control } \\
\text { Women: }\end{array}$ & $\begin{array}{r}9 \\
17\end{array}$ & $\begin{array}{l}1.54 \\
1.75\end{array}$ & $\left.\begin{array}{l}0.27 \\
0.26\end{array}\right\}$ & 0.03 \\
\hline $\begin{array}{l}\text { Back } \\
\text { Control }\end{array}$ & $\begin{array}{r}7 \\
16\end{array}$ & $\begin{array}{l}1.67 \\
1.68\end{array}$ & $\left.\begin{array}{l}0.20 \\
0.19\end{array}\right\}$ & 0.48 \\
\hline
\end{tabular}

Table 4 Results by race

\begin{tabular}{|c|c|c|c|c|}
\hline & No & $\begin{array}{l}\text { LS-S1 } \\
\text { canal } \\
\text { diameter } \\
(\mathrm{cm})\end{array}$ & $\begin{array}{l}\text { Standard } \\
\text { deviation }\end{array}$ & p Value \\
\hline $\begin{array}{l}\text { Whites } \\
\text { Non-whites } \\
\text { Whites: }\end{array}$ & $\begin{array}{l}38 \\
11\end{array}$ & $\begin{array}{l}1.68 \\
1.68\end{array}$ & $\left.\begin{array}{l}0.23 \\
0.26\end{array}\right\}$ & 0.5 \\
\hline $\begin{array}{l}\text { Back } \\
\text { Control } \\
\text { Non-whites: }\end{array}$ & $\begin{array}{l}11 \\
27\end{array}$ & $\begin{array}{l}1.57 \\
1.72\end{array}$ & $\left.\begin{array}{l}0.24 \\
0.22\end{array}\right\}$ & 0.03 \\
\hline $\begin{array}{l}\text { Back } \\
\text { Control }\end{array}$ & $\begin{array}{l}5 \\
6\end{array}$ & $\begin{array}{l}1.66 \\
1.69\end{array}$ & $\left.\begin{array}{l}0.28 \\
0.27\end{array}\right\}$ & 0.43 \\
\hline
\end{tabular}

$1.68 \mathrm{~cm}$. On the other hand, nine men in the back group had a mean L5-S1 diameter of $1.54 \mathrm{~cm}$ compared with $1.75 \mathrm{~cm}$ in the 17 male controls. This is a statistically significant difference $(p=0.029)$.

\section{BY RACE (table 4)}

No difference in canal size was noted between 38 whites and 11 non-whites. The mean canal diameter at the L5-S1 level for each subgroup was $1.68 \mathrm{~cm}$. Eleven whites in the back subgroup had a significantly smaller mean canal diameter than 27 control whites $-1.57 \mathrm{~cm}$ $v 1.72 \mathrm{~cm}(\mathrm{p}=0.03)$. Five non-whites in the back subgroup had a mean diameter less than six control non-whites $-1.66 \mathrm{~cm} v 1.69 \mathrm{~cm}$. This was not a significant difference, however $(p=0.43)$.

\section{Discussion}

Results from this case-control pilot study must be considered in the light of the weaknesses of the study itself, probably the most significant being the few people studied. Eleven films were not included in the analysis because the quality was too poor to permit reliable measurement and this was done with the agreement of two of the readers (DFA and DJA). Some were of obese subjects, the thickness of adipose tissue severely limiting the quality of the study. Most of the remaining poor films, primarily due to inexperience with the technique, came during the early days of the study. Refinements in technique were rather easily accomplished with experience. Measurements were best made from the A-mode display. Optimally, images might also be recorded on videotape for review and assessment of quality.

While this study has its limitations, it is significant that the results obtained are consistent with those reported elsewhere. For example, the lowest 10th percentile diameter at the L5-S1 level in the series of Porter et al was also below $1.4 \mathrm{~cm},{ }^{13}$ and $14 \mathrm{~mm}$ is considered to be the lower level of normal for the AP diameter of the lumbar spine as determined by myelography ${ }^{24}$ and by plain $x$ ray films. ${ }^{25}{ }^{26}$ Results are also consistent with those of Porter ${ }^{1213}$ and Mac- 
donald, ${ }^{16}$ using ultrasound, and Kornberg ${ }^{20}$ and Winston ${ }^{17}$ using other modalities (computed tomography and lumbosacral $x$ rays, respectively) that link narrow spinal canals with increased morbidity from low back problems. In the present study being in the lowest 10 th percentile for canal diameter was significantly associated with an increased likelihood of having missed time from work because of low back pain (odds ratio $10 \cdot 7$ ).

It is noteworthy that we could obtain such results in a pilot study after minimal training, using the technician and equipment of an ordinary hospital radiology department. We believe that, with some minor modifications of the recording programme to permit easier measurement, accuracy and interobserver consistency could be further improved.

The reasons for an association between small canal size and low back pain are not entirely clear but probably reflect on the neural content:canal ratio.? Free space exists between the outer bony/ligamentous lining of the lumbar and the dura and other inner linings, permitting tension free movements of neural contents within the spinal canal. This has been termed the "spinal reserve capacity." 15 As determined by computed tomography, the spinal reserve capacity is about $0.74 \mathrm{~mm}$ at the L3 and L4 levels and extremely variable at L5. ${ }^{15}$ Anything that would reduce this capacity could produce "disproportionately severe clinical signs." People with intrinsically narrow canals would probably have less spinal reserve capacity to start with, so it would take less of an insult (such as a smaller bulge of the annulus fibrosis, a lesser degree of osteophyte intrusion into the canal, or even the normal narrowing of the canal from age related periosteal calcification) to produce symptoms in those individuals than in those starting with wider canals.

This study confirms that it would be practicable to undertake further large scale studies to determine whether canal size could be of use as a screening test for preventing back problems. If those in the smallest 10th percentile can be proved to be at increased risk of developing low back pain (particularly if they can be shown to be the few cases that constitute the greatest expense), ultrasound could become a valuable screening tool in industry, permitting selective job placement or protective training, or both, for those at high risk.

We thank Kenneth Heinz for performing the ultrasound studies and Mrs Gwendolyn Sharpe for her help in identifying hospital personnel eligible to take part in the study.

\section{References}

1 Omenn GS, Morris SL. Occupational hazards to health care workers: report of a conference. Am J Ind Med 1984;6:129-37.
2 Morris A. Identifying workers at risk to back injury is not guesswork. Occup Health Saf 1985;54:16-20.

3 Moffett JAK, Chase SM, Portek I, Ennis JR. A controlled, prospective study to evaluate the effectiveness of a back school in the relief of chronic low back pain. Spine 1986;11:120-2.

4 Spengler DM, Bigos SJ, Martin NA, Zeh J, Fisher L, Nachemson A. Back injuries in industry: a retrospective study I. Overview and cost analysis. Spine 1986;11:241-5.

5 Sarpyener MA. Congenital stricture of the spinal canal. $J$ Bone Joint Surg 1945;27:70-9.

6 Verbiest $H$. A radicular syndrome from developmental narrowing of the lumbar vertebral canal. J Bone Joint Surg 1954;36-B: $230-7$.

7 Verbiest $H$. Neurogenic intermittent claudication in cases with absolute and relative stenosis of the lumbar vertebral canal (ASLC and RSLC), in cases with narrow lumbar intervertebral foramina, and in cases with both entities. Clin Neurosurg 1973;20:204-15.

8 Jones RAC, Thomson JLG. The narrow lumbar canal. A clinical and radiological review. J Bone Joint Surg 1968;50-B:595-605.

9 Wilson CB, Ehni G, Grollmus J. Neurogenic intermittent claudication. Clin Neurosurg 1971;18:62-85.

10 Kirkaldy-Willis WH, Paine KWE, Cauchoix J, McIvor G. Lumbar spinal stenosis. Clin Orthop 1974;99:30-50.

11 McIvor GWD, Kirkaldy-Willis WH. Pathological and myelographic changes in the major types of lumbar spinal stenosis. Clin Orthop 1976;115:72-6.

12 Porter RW, Hibbert CS, Wicks M. The spinal canal in symptomatic lumbar disc lesions. J Bone Joint Surg 1978;60-B:485-7.

13 Porter RW, Hibbert C, Wellman P. Backache and the lumbar spinal canal. Spine 1980;5:99-105.

14 Larsen JL, Smith D. Size of the subarachnoid space in stenosis of the lumbar canal. Acta Radiol (Diagn) 1980;21:627-32.

15 Weisz GM, Lee P. Spinal canal stenosis. Concept of spinal reserve capacity: radiologic measurements and clinical applications. Clin Orthop 1983;179:134-40.

16 Macdonald EB, Porter R, Hibbert C, Hart J. The relationship between spinal canal diameter and back pain in coal miners. Ultrasonic measurement as a screening test? J Occup Med 1984;26:23-7.

17 Winston K, Rumbaugh C, Colucci V. The vertebral canals in lumbar disc disease. Spine 1984;9:414-7.

18 Hall S, Bartleson JD, Onofrio BM, Baker HL, Okazaki H, O'Duffy JD. Lumbar spinal stenosis. Clinical features, diagnostic procedures, and results of surgical treatment in 68 patients. Ann Intern Med 1985;103:271-5.

19 Weisz GM. Lumbar canal stenosis an occupational hazard. Int Surg 1986;71:199-201.

20 Kornberg M, Rechtine GR. Quantitative assessment of the fifth lumbar spinal canal by computed tomography in symptomatic L4-L5 disc disease. Spine 1985;10:328-30.

21 Engel JM, Engel GM, Gunn DR. Ultrasound of the spine in focal stenosis and disc disease. Spine 1985;10:928-31.

22 Battie MC, Hansson TH, Engel JM, Zeh J, Bigos SJ, Spengler $\mathrm{DM}$. The reliability of measurements of the lumbar spine using ultrasound B-scan. Spine 1986;11:144-8.

23 Porter RW, Wicks M, Ottewell D. Measurement of the spinal canal by diagnostic ultrasound. J Bone Joint Surg 1978;60B:481-4.

24 Paine KWE, Huang PWH. Lumbar disc syndrome. J Neurosurg 1972;37:75-9.

25 Epstein JA, Epstein BS, Lavine L. Nerve root compression associated with narrowing of the lumbar spinal canal. $J$ Neurol Neurosurg Psychiatry 1962;25:165-76.

26 Eisenstein S. The morphometry and pathological anatomy of the lumbar spine in South African negroes and caucasoids with specific reference to spinal stenosis. J Bone Joint Surg 1977;59B: $173-80$. 